\title{
Comparrative Assay of Citalopram in Different Media
}

\author{
Safila Naveed ${ }^{1 *}$, Fatima Qamar ${ }^{1}$, Syeda Sarah Abbas ${ }^{1,2}$, Sania Zehra ${ }^{1}$, Sehrish Kirn ${ }^{1}$, Zohra Barkat ${ }^{1}$ and Syeda Zainab ${ }^{2}$ \\ ${ }^{1}$ Jinnah University for Women Karachi, Pakistan \\ ${ }^{2}$ University of Karachi, Pakistan \\ ${ }^{3}$ Federal Urdu University, Pakistan
}

\begin{abstract}
Citalopram is one of a class of antidepressants known as selective serotonin reuptake inhibitors. Citalopram blocks the reuptake of serotonin at the serotonin reuptake pump of the neuronal membrane, enhancing the actions of serotonin on $5 \mathrm{HT}_{1 \mathrm{~A}}$ autoreceptors. SSRIs bind with significantly less affinity to acetylcholine, histamine and norepinephrine receptors than tricyclic antidepressant drugs Using UV spectrophotometer a simple, economical least time consuming and accurate method for comparison of different brand of citalopram, has been developed. The assay is based on the UV absorbance maxima at about wavelength of $244 \mathrm{~nm}$ using distilled water as solvent. Four different brand of citalopram was dissolved in buffer of $\mathrm{pH} 1, \mathrm{pH} 4$ and water and then various dilutions are prepared (200 ppm, $100 \mathrm{ppm}, 50 \mathrm{ppm}$ and $25 \mathrm{ppm}$ ). The absorbance of these drugs was measured at $244 \mathrm{~nm}$ against the solvent blank and the assay was calculated by using the absorbance of active. We obtain linear relationship of four brands of citalopram when diluted to form 200 ppm, 100 ppm, 50 ppm, 25 ppm and absorbance of all brand are maximum in $\mathrm{pH} 4$.Squared correlation coefficient value of all the brands of citalopram are well within the limit.
\end{abstract}

Keywords: Antidepressants; UV spectrophotometer; Autoreceptors

\section{Introduction}

Citalopram is white to off white fine crystalline powder which is freely soluble in water chloroform and ethanol. Its melts at 182$183^{\circ} \mathrm{C}$ while boils at $175-181^{\circ} \mathrm{C}$. Chemical name of citalopram is 1-3-dimethylamino propyl-1-4-fluorophenyl-1, 3-dihydro-2benzofuran-5carbonitrile and molecular formula is $\mathrm{C}_{20} \mathrm{H}_{21} \mathrm{FN}_{2 \mathrm{O}}$ [1]. Citalopram is an antidepressant belonging to class "selective serotonin reuptake inhibitors" (SSRIs). Citalopram is used to treat depression related with anxiety, mood disorders and dysmorphic disorders. The antidepressant, anti bulimic and anti obsessive-compulsive activities, is due to inhibition of reuptake of serotonin in CNS [2]. In-vitro studies of citalopram shows that it is a potent and selective inhibitor of serotonin uptake ANS has less activity for reuptake of norepinephrine and dopamine [3]. It has no significant affinity for receptors such as cholinergic, GABA, histaminergic, dopaminergic, benzodiazepine or serotoninergic $5 \mathrm{HT} 1 \mathrm{~A}, 5 \mathrm{HT} 2,5 \mathrm{HT} 1 \mathrm{~B}$ and adrenergic $\alpha 1, \alpha 2, \beta$. It does not inhibit monoamine oxidase [4] Citalopram has rapid absorption in GI tract. Its peak plasma concentration is 4 hours; bioavailability is $80 \%$ by oral administration. Its absorption does not affected by food. $12-23 \%$ if drug eliminates in unchanged form through urine and $10 \%$ through feces [5]. It is highly lipophilic and widely distributed throughout the body it cross the blood brain barrier. Dimethylcitalopram is a metabolite of citalopram that cannot cross brain barrier [6]. It metabolizes through liver and metabolites which are formed are dimethyl citalopram, citalopram $\mathrm{N}$-oxide, and deaminated propionic acid derivatives. Enzymes that convert citalopram into different metabolites are CYP450, 3A4, 2C19, CYP2D6. Metabolites of citalopram have little effectiveness as compare to parent compound and donor contribute in clinical effect of drug. Citalopram $\mathrm{HBr}$ is a racemic bicyclic phthalane derivative designated ( \pm )-1-(3-dimethylaminopropyl)1-(4-fluorophenyl)-1, 3-dihydroisobenzofuran-5-carbonitrile, $\mathrm{HBr}$. The molecular formula is $\mathrm{C}_{20} \mathrm{H}_{22} \mathrm{BrFN}_{2 \mathrm{O}}$ and its molecular weight is 405.35 (Figure 1) [7]. Citalopram $\mathrm{HBr}$ is sparingly soluble in water and soluble in ethanol. $\mathrm{HBr}$ in strengths equivalent to $10 \mathrm{mg}$ citalopram base. Furancarbonitrile is one of the SSRI used as an antidepressant. The drug is also effective in reducing ethanol uptake in alcoholics and is used in depressed patients who also suffer from tardive dyskinesia in preference to tricyclic antidepressants, which exaggerate this condition [8].

A number of techniques are reported for the determination of enatiomeric citalopram that includes Spectrophotometric methods $[9,10]$, flourimetric methods $[9,10]$ capillary electrophoresis [11,12] electrochemical and chromatographic method [13-17]. The spectrophotometric methods include ethanol as a solvent. In our study de ionized water is used as a solvent which is cheaper than other solvents. Availability of the drug is also measured using different Buffer solutions i.e. $\mathrm{pH}$ lbuffer corresponds to the $\mathrm{pH}$ of empty stomach; $\mathrm{pH}$ 4 buffer corresponds to the $\mathrm{pH}$ of full stomach. We have done these types of assay for different drugs which are very useful for selection of best drugs [18-24].

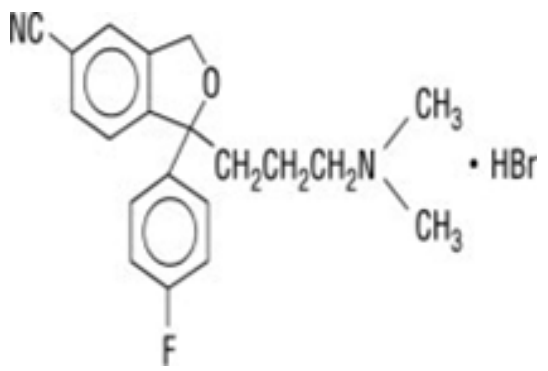

Figure 1: Structure of Citalopram.

*Corresponding author: Safila Naveed, Faculty of Pharmacy, Jinnah University for Women Karachi, Pakistan, Tel: 00923002621917; E-mail: safila117@yahoo.com

Received April 15, 2015; Accepted May 04, 2015; Published May 11, 2015

Citation: Naveed S, Qamar F, Abbas SS, Zehra S, Kirn S, et al. (2015) Comparrative Assay of Citalopram in Different Media. J Bioequiv Availab 7: 194196. doi:10.4172/jbb.1000238

Copyright: ( 2015 Naveed S, et al. This is an open-access article distributed under the terms of the Creative Commons Attribution License, which permits unrestricted use, distribution, and reproduction in any medium, provided the original author and source are credited. 
Citation: Naveed S, Qamar F, Abbas SS, Zehra S, Kirn S, et al. (2015) Comparrative Assay of Citalopram in Different Media. J Bioequiv Availab 7: 194-196. doi:10.4172/jbb.1000238

\section{Methodology}

\section{Experimental}

Material and reagents: Glass wares, beakers, volumetric flask, measuring cylinder, pipette and stirrer were used. All glass wares were washed and rinsed with double distilled water. Reagents used were as follows $0.1 \mathrm{~N}$ hydrochloric acid and de-ionized water or double distilled water. All the Reagents were of Analytical grade.

\section{Instruments}

Spectrophotometer with a quartz cuvette T80 UV-VI spectrometer 'PG Instrument', UV Lamp Power of 8N, Serial NO: N 045571, LF204.LS '4W-254 and 365 nm', Weighing Balance Item PA214C: 'Pioneer OHAIUS' and Water Bath 'HH-4' having digital and constant temperature tank.

\section{Preparation of $\mathrm{pH} 1$ and $\mathrm{pH} 4$ solution}

Methods Preparation of simulated gastric juice and buffers $0.1 \mathrm{~N}$ hydrochloric acid was prepared by diluting $9 \mathrm{~mL}$ hydrochloric acid of analytical grade $(11 \mathrm{~N})$ in a liter volumetric flask and the volume was made up to the mark with de-ionized water.

\section{Procedure}

The four different brands (cipram, manipram, citalo, pramcet) were purchased from the medical store located in Karachi, Pakistan. Accurately weighed $20 \mathrm{mg}$ of each tablet of four different brands of citalopram, 20 tablets were then crushed with the help of motor and pestle and transferred to volumetric flask and then sufficient $\mathrm{pH} 1$ was added to produce $100 \mathrm{ml}$ same procedure was repeated for $\mathrm{pH} 4$ and for water.

\section{Dilutions}

From the sample solution of different brands of citalopram different dilutions were made. Solutions of 200 ppm, 100 ppm, 50 ppm and $25 \mathrm{ppm}$ of all the three brands were prepared. After preparation of standard and capsule solutions, strength of solution $200 \mathrm{ppm}$ in $100 \mathrm{ml}$ and different dilutions absorbance of the sample preparation and standard preparation in $1 \mathrm{~cm}$ cell at the wavelength of maximum absorbance at about $244 \mathrm{~nm}$, using a spectrophotometer, using the blank solution. Calculate the quantity in $\mathrm{mg}$, of citalopram per capsule.

\section{Result and Discussion}

Pharmaceutical assay was carried out by using spectrophotometer on all brands of citalopram during the study. Tables 1 and 2 shows name brand and absorbance of different brands. Four different brands of citalopram (cipram, manipram, citalo, pramcet) are taken and their solutions of $200 \mathrm{ppm}, 100 \mathrm{ppm}, 50 \mathrm{ppm}$ and $25 \mathrm{ppm}$ are prepared. Their percent assay is calculated and regression equation and regression line is obtained to predict further availability of drug. For detect linearity solutions of $200 \mathrm{ppm}, 100 \mathrm{ppm}, 50 \mathrm{ppm}$ and 25 ppm is prepared and four absorbances in triplicate were taken at each level in spectrophotometric analysis. For linearity plot concentration vs. absorbance at level $200 \mathrm{ppm}, 100 \mathrm{ppm}, 50 \mathrm{ppm}$ and $25 \mathrm{ppm}$ is shown in Figures 1-6. Two and three squared correlation coefficient was found 0.9707 for brand A and 0.99 for brand B, C, D. It should not be less than 0.99 . Squared correlation coefficient value is well within the limit. After dilutions the absorbance of all four brands checked under $\mathrm{pH} 1$ and $\mathrm{pH} 4$ and from above figures the result is found to be that absorbance of four brands is maximum in $\mathrm{pH} 4$ that is citalopram is highly absorb in full stomach. A good linear relationship was observed

\begin{tabular}{|c|c|c|c|c|c|c|c|}
\hline TABLETS & WATER & Ph1 & Ph4 & 200ppm & 100ppm & 50ppm & 25ppm \\
\hline A (cipram ) & 2.735 & 2.317 & 2.577 & 2.735 & 2.523 & 1.662 & 0.881 \\
\hline B(manipram) & 2.694 & 2.366 & 2.626 & 2.694 & 2.411 & 1.4 & 0.706 \\
\hline C (citalo) & 2.675 & 2.341 & 2.635 & 2.675 & 2.038 & 1.076 & 0.531 \\
\hline D (pramcet) & 2.725 & 2.358 & 2.609 & 2.725 & 2.193 & 1.176 & 0.512 \\
\hline
\end{tabular}

Table 1: Absorbance of different brand of citalopram in different medium.

\begin{tabular}{|c|c|c|c|}
\hline $\begin{array}{c}\text { BRANDS } \\
\text { STRENGHT }\end{array}$ & STRENGTH & $\begin{array}{c}\text { REGRESSION } \\
\text { EQUATION }\end{array}$ & $\begin{array}{c}\text { CORELATION } \\
\text { COEFFICIENT }\end{array}$ \\
\hline $\mathrm{A}$ (cipram ) & $20 \mathrm{mg}$ & $\mathrm{y}=0.0234 \mathrm{x}+0.2777$ & 0.9707 \\
\hline $\mathrm{B}$ (manipram) & $20 \mathrm{mg}$ & $\mathrm{y}=0.0234 \mathrm{x}+0.1152$ & 0.9921 \\
\hline $\mathrm{C}$ (citalo) & $20 \mathrm{mg}$ & $\mathrm{y}=0.0203 \mathrm{x}+0.0222$ & 0.9988 \\
\hline $\mathrm{D}$ (pramcet) & $20 \mathrm{mg}$ & $\mathrm{y}=0.0223 \mathrm{x}-0.0147$ & 0.9967 \\
\hline
\end{tabular}

Table 2: Regression equation and Correlation Coefficient of different brand of citalopram.
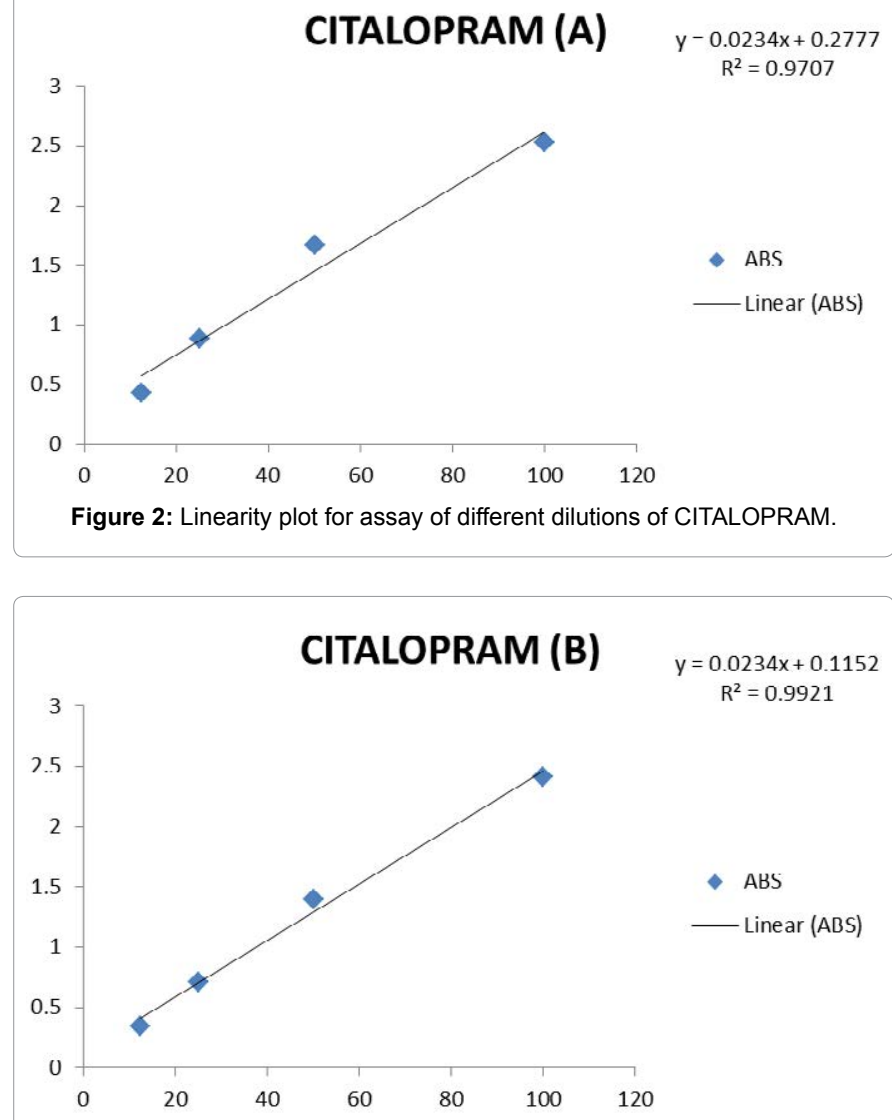

Figure 3: Linearity plot for assay of different dilutions of CITALOPRAM.

for cipram, manipram, pramcet, and citalo the concentration ranges of $200 \mathrm{ppm}, 100 \mathrm{ppm}, 50 \mathrm{ppm}$ and $25 \mathrm{ppm}$. The correlation coefficient for citalopram was found to be 0.9707 for brand A and 0.99 for brand B, C, D. Squared correlation coefficient value is well within the limit. Absorbance of all four brands of citalopram is maximum in $\mathrm{pH} 4$ (shows maximum absorbance in full stomach).

\section{Conclusion}

Pharmaceutical assay was carried out by using spectrophotometer on all brands of citalopram during the study. A good linear relationship was observed for cipram, manipram, pramcet, and citalo the 
Citation: Naveed S, Qamar F, Abbas SS, Zehra S, Kirn S, et al. (2015) Comparrative Assay of Citalopram in Different Media. J Bioequiv Availab 7: 194-196. doi:10.4172/jbb.1000238

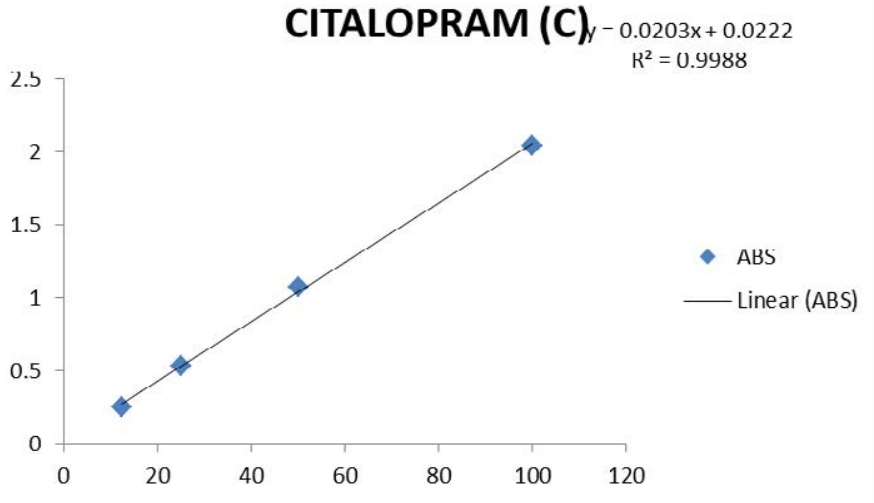

Figure 4: Linearity plot for assay of different dilutions of CITALOPRAM.

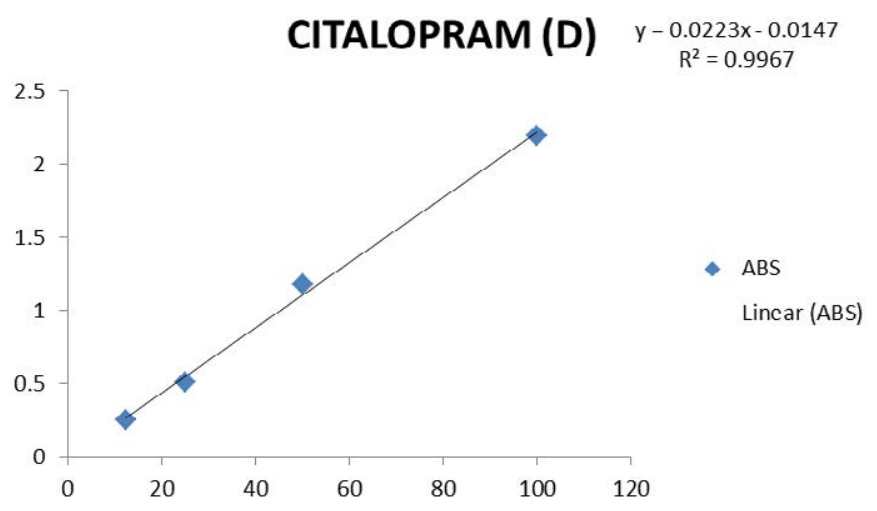

Figure 5: Linearity plot for assay of different dilutions of CITALOPRAM.

\section{CITALOPRAM}

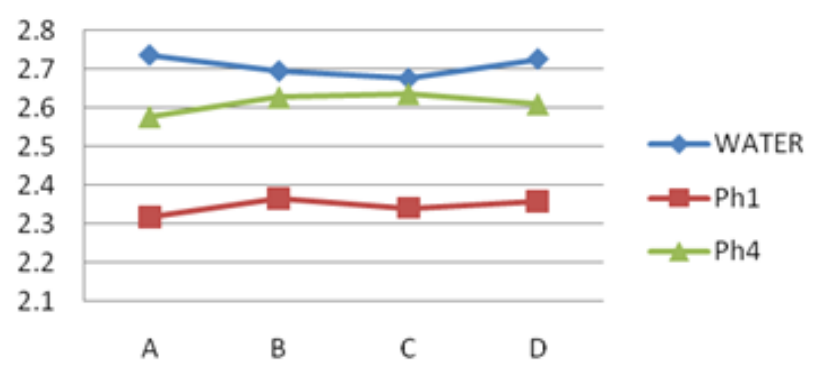

Figure 6: Absorbance of different brand of citalopram in different medium.

concentration ranges of $200 \mathrm{ppm}, 100 \mathrm{ppm}, 50 \mathrm{ppm}$ and $25 \mathrm{ppm}$. The correlation coefficient for citalopram was found to be 0.9707 for brand A and 0.99 for brand B, C, D. Squared correlation coefficient value is well within the limit. Absorbance of all four brands of citalopram is seen increased in $\mathrm{pH}$ 4. This method can be used for routine analysis in pharmaceutical industry as this method is simple.

\section{Reference}

1. Sindrup SH, Bjerre U, Dejgaard A, Brosen K, Aaes-Jorgensen T, et al. (1992) The selective serotonin reuptake inhibitor citalopram relieves the symptoms of diabetic neuropathy. Clin Pharmacol Ther 52: 547-552.

2. Atmaca M, Kuloglu M, Tezcan E, Semercioz A (2002) The efficacy of citalopram in the treatment of premature ejaculation: a placebo-controlled study. Int J Impot Res 14: 502-505.

3. Andersen G, Vestergaard K, Riis JO (1993) Citalopram for post-stroke pathological crying. Lancet 342: 837-839.

4. Clayton A, Keller A, McGarvey EL (2006) Burden of phase-specific sexual dysfunction with SSRIs. J Affect Disord 91: 27-32.

5. Baumann P (1996) Pharmacology and pharmacokinetics of citalopram and other SSRIs. Int Clin Psychopharmacol 11 Suppl 1: 5-11.

6. FDA labe

7. Hyttel J, Bogeso KP, Perregaard J, Sanchez C (1992) The pharmacological effect of citalopram residues in the (S)-(+)-enantiomer. J Neural Transm Gen Sect 88: 157-160.

8. Caccia S (1998) Metabolism of the newer antidepressants. An overview of the pharmacological and pharmacokinetic implications. Clin Pharmacokinet 34 281-302.

9. Raza A (2006) Development and application of spectrophotometric methods for the determination of citalopram hydrobromide in dosage forms. Chem Pharm Bull (Tokyo) 54: 432-434

10. Pillai S, Singhvi I (2006) Application of orange G dye for quantitation of citalopram hydrobromide, donepezil hydrochloride and rabeprazole sodium from tablet formulation. Indian J Pharm Sci 68: 682-684.

11. Serebruany V, Malinin A, Dragan V, Atar D, van Zyl L, et al. (2007) Fluorimetric quantitation of citalopram and escitalopram in plasma: developing an express method to monitor compliance in clinical trials. Clin Chem Lab Med 45: 513520.

12. El-Sherbiny DT (2006) Spectrofluorometric determination of citalopram in pharmaceutical preparations and spiked human plasma using organized media. J AOAC Int 89: 1288-1295.

13. Andersen S, Halvorsen TG, Pedersen-Bjergaard S, Rasmussen KE, Tanum L, et al. (2003) Stereospecific determination of citalopram and desmethylcitalopram by capillary electrophoresis and liquid-phase microextraction. J Pharm Biomed Anal 33: 263-273.

14. Mandrioli R, Fanali S, Pucci V, Raggi MA (2003) Enantiomeric separation of citalopram and its metabolites by capillary electrophoresis. Electrophoresis 24 2608-2616.

15. Nouws H, Delerue-Matos C, Barros A (2006) Electrochemical Determination of Citalopram by Adsorptive Stripping Voltammetry-Determination in Pharmaceutical Products. Anal Lett 39: 1907-1915.

16. Nilesh D, Santosh G, Shweta S, Kailash B (2008) Simultaneous HPTLC Determination of Escitalopram Oxalate and Clonazepam in Combined Tablets. Chromatographia 67: 487-490.

17. Greiner C, Hiemke C, Bader W, Haen E (2007) Determination of citalopram and escitalopram together with their active main metabolites desmethyl(es-) citalopram in human serum by column-switching high performance liquid chromatography (HPLC) and spectrophotometric detection. J Chromatogr B Analyt Technol Biomed Life Sci 848: 391-394.

18. Naveed S (2014) Simple UV spectrophotometric assay of Atorvastatin API formulation and their comparative study. Global Journal of Medical Research 14: $35-38$.

19. Naveed S, Qamar F (2014) A simple assay of Esomeprazole Using UV spectrophotometer. The Global Journal of Pharmaceutical Research 3: 1921 1925 ,

20. Naveed S, Qamar F (2014) Simple UV spectrophotometric assay of Mefenamic acid. International Journal of Pharma Sciences and Research 5: 364-366.

21. Naveed S, Shah SN, Qamar F , Waheed N, Nazeer S (2014) Simple UV spectrophotometric assay of new formulation gentamycin. J App Pharm Vol 6: 407-410.

22. Naveed S, Shah SN, Qamar F, Waheed N, Nazeer S (2014) Simple UV spectrophotometric assay of Lincomycin. IJPRDD 1: 10-12.

23. Naveed S, Nawab A (2014) Assay of LVFX (levofloxacin) in different formulation by UV spectroscopy. IJPRDD 1: 13-16.

24. Naveed S and Qamar F (2014) Simple UV spectrophotometric assay of Metronidazole. Open Access Library Journal 1. 